\section{A monument to folly}

In the county of Buckinghamshire in England, about halfway between Buckingham and Bicester, the busy main road (the A421) connecting these two towns is crossed by a still-impressive railway bridge (Figure 1), solid enough to still be standing even though the line it carries was closed in 1966, one of the victims of an incredibly short-sighted, massive truncation of Britain's railway network (the "Beeching axe"). The bridge is a monument to the professionalism of the engineers and contractors who designed and built it (the line, part of the Great Central Railway, was opened in 1899). Its solidity is reminiscent of British-built railways in Argentina, maintenance of which appears to have ceased on the day of nationalization in 1948, but on some lines of which freight trains still run - at walking pace - ignoring the semaphore signals that still proudly stand, connected to abandoned signal boxes, which in turn are connected by telegraph wires, whose supporting poles sometimes now stand at crazy angles, with the wires trailing along the ground in places. Infrastructure like the massive cast iron station nameplates seems to be indestructible.

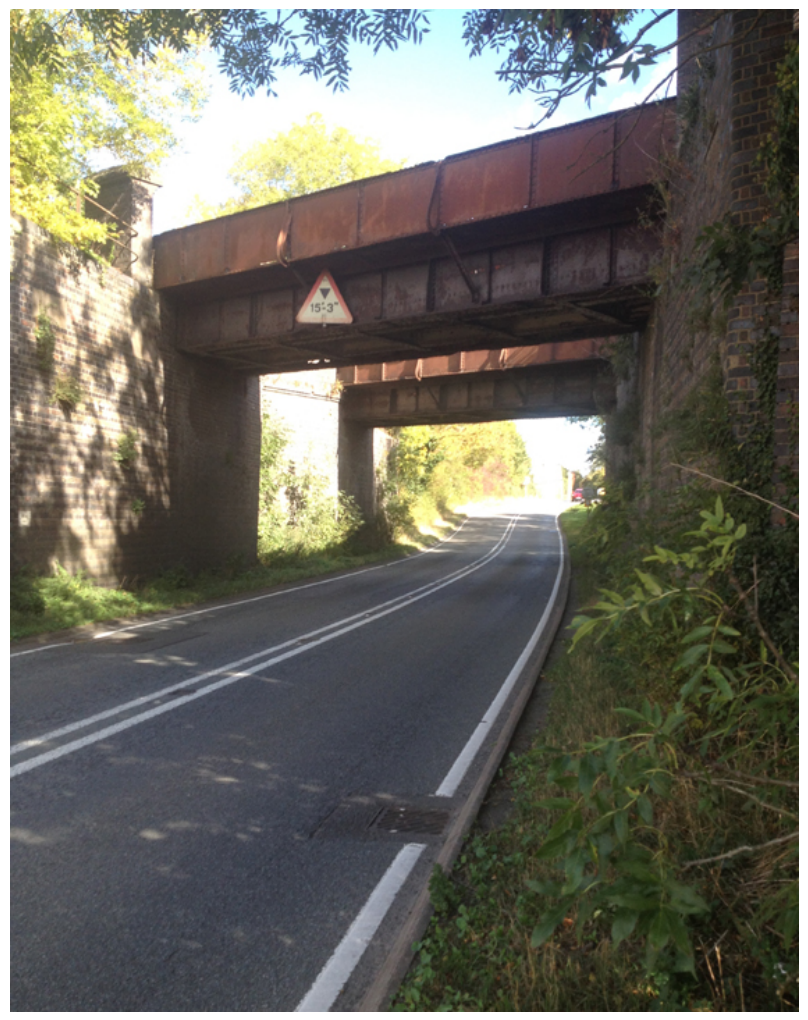

Figure 1. The bridge of the former Great Central Railway over the A421 road, just south of the former Finmere station in Buckinghamshire, England (photographed in October 2018).
In Britain today, a highly divisive issue is whether to construct a new high-speed railway line from London to the Midlands and northern cities such as Manchester and Leeds. The line, called HS2, would be a successor to the successful HS1, which was completed in 2007 and runs from St Pancras station in London to the Channel Tunnel near Folkestone. Its primary function is to carry the high-speed expresses from Paris and Brussels to London. HS2 is not designed to connect to HS1, although since all these lines use the "standard" gauge of 4' $8 \frac{1}{2}$ ", presumably it would be possible for through trains to run from, say, Manchester to Paris. Criticisms of HS2 include its astronomical cost-more than ten times the amount per kilometre of the French TGV [1], the despoilation of some lovely countryside in Buckinghamshire - picturesque small valleys that would become dominated by the railway-and elsewhere (England is a much more crowded country than France), and the very modest envisaged reduction in travelling times, to which the usual response is that the railway is needed to provide extra carrying capacity; a weightier response is that if trains are comfortable and reliable enough to allow productive work to be done on the journey, there is little merit in slightly shortening the journey time. Ironically enough, the route might even follow the track of the Great Central Railway where it crosses the A421.

Above all, the HS2 project lacks credibility because of the appalling track record of stewardship of Britain's railways since their nationalization, also in 1948 . Particularly reprehensible was the closure of about half the network in the 1950s and 1960s. Voices of reason challenging this policy were ignored (hence it cannot be argued that only hindsight allows one to call it folly); national transport policy then favoured motorways over railways, and the latter were sacrificed to the former (although many branch lines, as well as trunk routes, were closed). Antipathy towards the railway system continued during the years of Margaret Thatcher's prime ministership, possibly because at that time the railways were a bastion of trades unionism, which Mrs Thatcher wished to weaken. ${ }^{1}$

Even if the extreme scantiness of traffic passing over a particular line warranted its closure, the land should have been retained, not least because of the great trouble of acquiring in the first place - requiring an Act of Parliament - the long thin strips of land needed for railway operation. Instead, strenuous efforts were made

1 Likewise, Mrs Thatcher's pioneering enthusiasm for measures to combat climate change (such as diminishing the burning of coal) was likely driven by the desire to weaken the very strong trades unions in the mining industry. 
to sell off the land made surplus by the mass closures; in 1970 the British Rail Property Board was formed to continue and intensify these efforts. It was said that the revenues from the land sales were helping to repay the war debt. Since the emergence of private train operating companies (following the Railways Act 1993) rail usage has doubled and there is now indeed serious undercapacity on many routes. The train operating companies are calling for stations and lines to be reopened; reopening is far simpler if the land is still owned by the railway. In London, the 20 ha Rossmore Road freight terminal of the Great Central Railway, next to Marylebone station, was sold for housing development after closure of the main line in 1966; were it still in possession of the railway, it could perhaps have been used as the London terminal of HS2, the planning of which is now causing an immense headache.

Nevertheless, even when the land has been retained, the process of reopening lines seems to move at glacial speed. A good example is the Oxford to Cambridge line, the closure of which was not included in the Beeching plan. Reopening has been repeatedly delayed and even the small section between Bicester and Bletchley may take another four or five years. A reason for the delay does not seem ever to have been given; it appears to be due simply to undercapacity in the rail infrastructure industry. A further criticism of HS2 is that the money required - probably around 100 milliard GBP — could be spent instead on rapidly reopening closed lines with far greater and swifter return.

The Bedford to Cambridge section will doubtless take much longer to reopen because much of the land has been sold, although in that particular case, given the predominantly flat terrain and the change in population distribution in the last 150 years since the original line was opened, that sale provides the opportunity to construct a better route. In general, though, land rendered surplus by closure, including redundant goods yards next to passenger stations remaining open, could have been leased, providing a valuable revenue stream (albeit at odds with the 1980s policy of selling off non-railway, but railway-related, businesses such as hotels and ferries). In some cases the land was retained and repurposed into revenue-generating commuter car parks. A more visionary approach could have seen individual rural stations becoming hotbeds of local entrepreneurialism (cf. the reinvigoration of subpost offices by the injection of commercial enterprise).

Above all, retaining land would have kept options open, and allowed the railways to respond far more effectively to rapidly growing demand. Few at the time of the mass closures could have foreseen the enormous development of electronic data processing, which is particularly adaptable to increasing the efficiency of running a railway. A very contemporary preoccupation is energy efficiency: in this respect the superiority of rail over other means of rapid transport makes it a clear winner in the fight to decarbonize, alongside the fact that electrification of motive power is very well established on the railways, while still in its infancy for road transport, and barely inchoate for air transport.

The rise of the private car was the main factor in the decline of rail usage following the First World War; the increase during the last couple of decades may be driven by the increasingly intolerable crowdedness of roads in the UK and the increasingly intrusive regulation of driving, which is becoming intolerable to experienced motorists. While the inability to carry out written work in a motor-car, even as a passenger, makes a car journey dead time compared with a journey by train, the introduction of mobile telephones has partly compensated for that, although regulation - in this case probably still too lenient-is making their use more difficult. Note that the increase in rail usage has happened despite the dramatic increase in flights within the UK and to continental destinations nowadays readily accessible by train, and the equally dramatic decrease in air fares.

Apart from the impending transformation of road vehicle motive power from fossil-fueled internal combustion engines to electric motors powered by storage batteries or hydrogen fuel cells, it is widely expected that road vehicles will become autonomous. It would, however, be advisable not to be too sanguine about this development. In principle the software problems of autonomous control have been solved. Nevertheless, there have been some recent setbacks during road testing. While autonomous vehicles might be very successful if they are the only kind of vehicle on the road, the inevitable transition when there are both humandriven and autonomous vehicles sharing the road might be problematic. Legal issues of responsibility and liability are far from solved. Roadside foliage - from the trees that we are supposed to be intensively planting to aid decarbonization - may interfere with the electromagnetic signals used to communicate with other vehicles on the road. It is envisaged that it may no longer be necessary for individuals to own a car - they can simply summon an autonomous one when they need it - but this will not ease traffic congestion, it will only diminish the need for parking space. And it looks as though there will still be a legal requirement for a human being to be in overall command of each autonomous vehicle, meaning that journeys will still be dead time, and exceedingly boring for the "driver", who will no longer benefit from the mental 
stimulus of controlling the vehicle. Alongside the huge infrastructure deficits for battery recharging or hydrogen refueling, these problems may continue to encourage the rise in rail usage, in which case a far more extensive programme of construction than hitherto will be needed to ensure that all significant ${ }^{2}$ centres of population are connected to the system. ${ }^{3}$

J.J. RAMSDEN

\section{Reference}

1. Ramsden, J.J. Railways and civilization. J. Biol. Phys. Chem. 16(2016) 123-125.

2 "Significance" could be established by some objective criterion, such as town population, or a set of criteria.

3 Alternatively, places not connected might simply atrophy. 